\title{
EFFECTS OF SALINE CONDITIONS ON POLYPHENOL AND PROTEIN CONTENT AND PHOTOSYNTHETIC RESPONSE OF DIFFERENT OLIVE (OLEA EUROPAEA L.) CULTIVARS
}

\author{
DEMIR, S. ${ }^{1}-$ CETINKAYA, $\mathrm{H}^{2^{*}}$ \\ ${ }^{1}$ Graduate School of Natural and Applied Sciences, Kilis 7 Aralık University, Kilis, Turkey \\ ${ }^{2}$ Department of Horticulture, Faculty of Agriculture, Kilis 7 Aralık University, Kilis, Turkey \\ *Corresponding author \\ e-mail: hcetinkaya67@gmail.com; phone: +90-348-814-2666/7214
}

(Received 24 $4^{\text {th }}$ Jul 2019; accepted $15^{\text {th }}$ Nov 2019)

\begin{abstract}
Physiological responses of plants against biotic and abiotic stresses limit plant cultivation. The present study was designed to investigate the changes in polyphenol and protein content and photosynthetic response in different olive cultivars under influence of saline conditions. For this, the effects of different sodium chloride $(\mathrm{NaCl})$ salinity levels $(0,75$, and $150 \mathrm{mM})$ on physiological and biochemical parameters of Olea europaea L. cultivars (Gemlik, Kilis Yaglık, and Nizip Yaglık) were investigated. The highest total chlorophyll content was obtained under $75 \mathrm{mM}$ salinity level while the lowest one was determined under $150 \mathrm{mM}$ salinity. With respect to the cultivars, the highest chlorophyll content was found in Kilis Yaglik cv. whereas the lowest value was obtained from Gemlik. However, flavonoid content was determined to be highest under $150 \mathrm{mM}$ but lowest under $75 \mathrm{mM}$ salinity level. Regarding cultivars, total flavonoid content was ascertained for Gemlik cv. while it was lowest for Kilis Yaglik cv. Accordingly, it can be deduced that salinity decreased the chlorophyll content and cultivars showed different reactions against salinity and its doses. In addition, it influenced total phenolic and protein content in small quantities except for flavonoids which were differently synthesized against salinity levels.
\end{abstract}

Keywords: Gemlik, Kilis Yaglik, Nizip Yaglik, olive cultivar, salt stress, phenolic content, flavonoid content

\section{Introduction}

Historically, plants have been extensively used for medicinal, nutritional, flavoring, cosmetic and industrial purposes. Of those plants, Olea europaea L. belonging to the Oleaceae family is one of the most widely grown fruit crops in the countries of the Mediterranean basin and Turkey is one of the important producer and stakeholders of olive and olive oils. Origin and homeland of olive tree is considered to be the eastern Mediterranean Basin, Syria, central Mesopotamia and Anatolia. The existence of a large number of native wild olive trees in Anatolia reinforces this theory. Archaeological studies revealed that olives were cultivated and evolved in the Mediterranean Basin about 6000-7000 years ago and it then moved on and spread initially in the Aegean, later on in the central and western Mediterranean, and from there it spread to the other places (Ozkaya et al., 2009; Zohary et al., 2012; Breton et al., 2012; Kostelenos and Kiritsakis, 2017). Olea europaea L. has many cultivars and genotypes widely distributed in the southern parts of Turkey near Syrian border which is a semi-arid part. In this region, it is possible to see the sub-varieties and rich biological diversity of the species. The cultivars (cv. Gemlik, Kilis Yaglık and Nizip Yaglık) herein are the most commonly cultivated olive tree in this part.

Stress in plant cultivation is defined a number of regressions resulting in low yield and decline plant growth due to abiotic stress (salinity, drought, nutrient deficiencies or excesses, heavy metals, low and high temperatures, air pollution, radiation) and biotic 
stress (bacteria, fungus, viruses etc. and pests). Drought and salinity are the most important abiotic stress factors that limit agricultural production in the world. Approximately $45 \%$ of the world's agricultural land is constantly exposed to drought stress, while about $6 \%$ of the world's surface is suffering from salinity (Asraf and Foolad, 2007). Salinity is one of the important environmental abiotic stresses that adversely affect plant growth, yield, quality and soil fertility (Ozturk et al., 2004; Debez et al., 2004; Zehtab-Salmasi, 2008). Under natural climatic conditions, plants are routinely subjected to the environmental conditions, which affect plants growth, development and subsequently or consequently primary or secondary metabolite contents but the effects depend on the type, duration and magnitude of abiotic or biotic factors. Plants in general have given various biochemical and physiological responses to the biotic or abiotic stress (Bray et al., 2000). Physiology and biochemistry of plants such as photosynthesis, protein synthesis and energy and lipid metabolism are affected by salinity and that may result growth inhibition, fading or death of plants (Hamouda et al., 2015; Ahmad et al., 2016). Results such as toxicity, deterioration in mineral metabolism, consequently decline in productivity and yield can be observed in the biochemical and physiological processes of plants due to detrimental effects of high salinity. However, plant behavior can change with respect to the secondary metabolite synthesis, production, secretion, and storage during onset and development of salt stress or drought stress (Khalid and Da Silva, 2010; Ozkan and Kulak, 2013). Irrigation with saline water may effect growth of plants. In salinity exposed plants a significant reduction of shoot elongation and $\mathrm{Na}$ accumulation, an enhancement of cells area and a thickening of epidermis, cuticle, hypodermis and outer mesocarp were observed. These alterations could be considered that plant protection against stress factors. So it must be applied a proper irrigation management with saline water for fruit production and olive tree quality (Moretti et al., 2018).

In some areas it is important to estimate the effects of irrigation-induced salinity on olive oil phytochemicals and bioactivities because of irrigation with recycled wastewater or salty groundwater. Effect of saline water irrigation on tree physiological parameters in different olive varieties at various salinity levels have been examined by many researchers. In this context, they have examined tree growth, fruit and oil yield, tree nutritional status, oil content and fruit characteristics, mechanisms of salt tolerance in olives and differences among cultivars in these studies (Chartzoulakis et al., 2006; Melgar et al., 2009; Ben-Gal, 2011; Kchaou et al., 2013; Moretti et al., 2018; Trabelsi et al., 2019; Tietel et al., 2019). Olive trees are able to resist water and salt stresses. Decreasing in total chlorophyll content, leaf water potential and photosynthetic gas exchange are observed in rainfed olive trees during drought. But half of their photosynthetic activity of olive leaves are permanently lost during to drought without irrigation and after being exposed to severe water or salt stress, they are unable to recover their whole photosynthetic capacity. However, they were not able to totally recover their physiological performance after re-watering (Tabelsi et al., 2019).

Leaves and roots of different pistachio rootstocks have given different physiological responces to salinity. Therefore, improving salt-tolerant genotypes are important for cultivation (Akbari et al., 2018).

Phenolic compounds are synthesized in plants via the shikimic acid metabolic pathway and endogenously controlled process during developmental differentiation. But their biosynthesis can be regulated by exogenous and stress factors such as light, temperature, drought, salinity, cold etc. (Crozier et al., 2006; Waśkiewicz et al., 2013). 
Phenolic compounds play an important role in scavenging free radicals and protect plants against the damaging effects of reactive oxygen species due to salt and drought stresses (Petridis et al., 2012; Waskiewicz et al., 2013). On the other hand salt stress has effects on the lipid and phytochemicals and it has increased polyphenol contents of olive oil. The increased levels of polyphenols in response to increasing salinity level show that exposure to salinity probably due to stress response to high salt levels. Polyphenol augmentation of olive oil was previously reported in response to various tree stress conditions involving, e.g., water, salinity, and drought (Artajo et al., 2006; Ben Ahmet et al., 2012; Tietel et al., 2019).

Southeast part of Turkey has major agricultural areas for crop production. Most of these crops are grown under dry conditions. With the development of irrigation systems, irrigation has become widespread in this region in recent years. Salinity problems arise with the irrigation of the orchards. Pistachios and olives are the most grown crops in this region. Kilis Yaglik, Nizip Yaglik and Gemlik olives are widely grown olive cultivars. Thus, present study was designed to investigate the alterations in polyphenol and protein content and photosynthetic response in three important and widely cultivated olive cultivars in response to the saline conditions.

\section{Material and Methods}

\section{Plant material}

The study was conducted with three cultivars of olive common in the study region (Kilis, Turkey), namely Gemlik, Kilis Yaglık and Nizip Yaglık.

\section{Growth conditions and salt treatment}

The present study was carried out according to the method with slight modifications (Demiral et al., 2011) differing with cultivars and stress exposure time. In the study, three olive cultivars (Gemlik, Kilis Yaglık and Nizip Yaglık) were used. The experiment was conducted using irrigation water with 2 different salinity levels (75 and $150 \mathrm{mM}$ ). The salinity levels were adjusted by the addition of appropriate amounts of $\mathrm{NaCl}$ to half-strength Hoagland's solution. The experiments were conducted in pots and arranged as a factorial, using a randomized complete design with three replications and one plant per pot. The seedlings were grown for one month using half-strength Hoagland's solution before the application of saline solutions to the plants were subjected. Experiments were conducted in a greenhouse with a 14-hour photoperiod and lasted 4 months (August-December). Mean temperature and relative humidity were 26$30^{\circ} \mathrm{C}$ during day and $16-20^{\circ} \mathrm{C}$ at night, $60 \%$, respectively. All plants were irrigated twice week with half-strength Hoagland solution. Before the flowering period, uniform sized leaves were detached from the same plant parts and immediately stored $-80^{\circ} \mathrm{C}$ until analysis. The soil mixture was included with soil: peat: perlite $(3: 1: 1)$.

\section{Preparation of extracts}

The air-dried and finely powdered leaves of olive cultivars $(5 \mathrm{~g})$ were stirred with $100 \mathrm{ml}$ of pure methanol for $30 \mathrm{~min}$, respectively. Extraction was carried out using maceration at room temperature for $24 \mathrm{~h}$ followed by filtration through Whatman No.4 filter paper. The extracts were then concentrated in vacuo at $40^{\circ} \mathrm{C}$ using a Rotary evaporator. Then the extracts were preserved in sealed vials at $4^{\circ} \mathrm{C}$ until further analysis. 


\section{Photosynthetic pigment and total protein determination}

The contents of chlorophyll $a$, chlorophyll $b$ and total chlorophyll $a+b$ in the leaves were determined, according to the method of Arnon (1949). Protein content in the crude extracts was determined after TCA precipitation according to the method of Bradford (1976), using bovine serum albumin (BSA) as a standard. The measurements were done using three replicates corresponding to the five samples for each replicate.

\section{Determination of total phenolic content}

Total phenolic content was determined according to the Folin-Ciocalteu reagent method (Singleton et al., 1999). The amount of total phenol was calculated as $\mathrm{mg} / \mathrm{g}$ (Gallic Acid Equivalents) from calibration curve of Gallic acid standard solution $\left(\mathrm{R}^{2}=0.9993\right)$. An aliquot of each sample $(0.1 \mathrm{ml})$ was diluted to $1 \mathrm{ml}$ with distilled water. Briefly, $0.5 \mathrm{ml}$ of Folin-Ciocalteu reagent $(1: 1 \mathrm{v} / \mathrm{v})$ and $1.5 \mathrm{ml}$ of $20 \%(\mathrm{w} / \mathrm{v})$ sodium carbonate were added to the diluted sample solution, and the mixture was then vortexed and allowed to stand for 2 hours at room temperature for color development. The volume was completed to $10 \mathrm{ml}$ with distilled water and their absorbance was measured at $765 \mathrm{~nm}$ (Evolution $201 \mathrm{UV}$-Visible Spectrophotometer).

\section{Determination of total flavonoid content}

The flavonoid content was determined by aluminum chloride method using quercetine as a reference compound (Kumaran and Karunakaran, 2006). This method based on the formation of a complex flavonoid-aluminum. The amount of total flavonoid was calculated from calibration curve of quercetine standard solution $\left(\mathrm{R}^{2}=0.9815\right) .1 \mathrm{ml}$ of olive leaf extracts or standards catechol solution $(500 \mu \mathrm{g} / \mathrm{ml})$ was added to $4 \mathrm{ml}$ distilled water and $0.3 \mathrm{ml}$ of $5 \% \mathrm{NaNO}_{2}$ was added. After 5 minutes, 0.3 $\mathrm{ml}$ of $10 \% \mathrm{AlCl}_{3}$ was added. After $6 \mathrm{~min}, 2 \mathrm{~mL}$ of $1 \mathrm{~mol} \mathrm{~L}-\mathrm{NaOH}$ was added and final total volume was completed to $10 \mathrm{~mL}$ with distilled water. Afterwards the absorbance of the mixture was measured at $510 \mathrm{~nm}$.

\section{Statistical analysis}

Three replications were used for each treatment. Data were expressed as mean. The experiments were arranged as a split plot design with three MSTAT-C statistical program was used to determine statistical significance levels and the differences between individual averages were considered to be statistically important at $\mathrm{p}<0.01$. Herein, one-way variance analysis followed by post-hoc tests of Duncan and regression analysis was performed to determine the differences between the cultivars and applied doses of salt.

\section{Results}

\section{Photosynthetic pigment content}

Leaf chlorophyll a, chlorophyll $\mathrm{b}$, and total chlorophyll content in relation to salt stress effects are collectively represented in Table 1 and Table 2. Determination of chlorophyll content in plants is an important indicator for photosynthesis capacity. The effects of different concentration of saline conditions on photosynthetic pigments were statistically significant $(\mathrm{P} \leq 0.01)$. There were also statistically significant differences 
associated with different olive cultivars and concentration levels of sodium chloride $(\mathrm{P} \leq 0.01)$. The highest content of photosynthetic pigments was determined in $75 \mathrm{mM}$ whereas the lowest content was ascertained in $150 \mathrm{mM} \mathrm{NaCl}$ concentration. Chlorophyll a content was the highest at $75 \mathrm{mM}$ concentration in Nizip Yaglik cultivar, the lowest at Gemlik cultivar control group. Chlorophyll b content was the highest at 75 $\mathrm{mM}$ concentration in Kilis Yaglik cultivar, the lowest at $150 \mathrm{mM}$ concentration in Gemlik cultivar.

Table 1. Chlorophyll a, chlorophyll b, and total chlorophyll content of olive cultivars leaves at different $\mathrm{NaCl}$ concentration

\begin{tabular}{c|c|ccc|c|ccc|c|ccc|c}
\hline & \multirow{2}{*}{$\begin{array}{c}\text { NaCl } \\
(\mathbf{m M})\end{array}$} & \multicolumn{4}{|c|}{ Chlorophyll a } & \multicolumn{4}{c|}{ Chlorophyll b } & \multicolumn{4}{c}{ Total Chlorophyll } \\
\cline { 3 - 12 } & I & II & III & Ave. & I & II & III & Ave. & I & II & III & Ave. \\
\hline \multirow{4}{*}{ Gemlik } & $\mathbf{0}$ & 2.53 & 3.06 & 3.59 & $\mathbf{3 . 0 6 0} \mathbf{h}$ & 1.04 & 1.57 & 2.10 & $\mathbf{1 . 5 4 7} \mathbf{~ f f}$ & 1.57 & 4.10 & 4.63 & $\mathbf{5 . 1 5 5}$ \\
& $\mathbf{7 5}$ & 2.99 & 3.52 & 4.05 & $\mathbf{3 . 5 2 0} \mathbf{f}$ & 1.15 & 1.68 & 2.21 & $\mathbf{1 . 6 8 2} \mathbf{~ e e}$ & 1.68 & 4.67 & 5.20 & $\mathbf{5 . 7 3 0}$ \\
& $\mathbf{1 5 0}$ & 2.18 & 2.71 & 3.24 & $\mathbf{2 . 7 0 8} \mathbf{~}$ & 0.93 & 1.46 & 1.98 & $\mathbf{1 . 4 5 5} \mathbf{g g}$ & 1.46 & 3.63 & 4.16 & $\mathbf{4 . 6 9 2}$ \\
\hline \multirow{3}{*}{ Kilis } & $\mathbf{0}$ & 4.16 & 4.75 & 5.35 & $\mathbf{4 . 7 5 3} \mathbf{d}$ & 1.55 & 2.15 & 2.74 & $\mathbf{2 . 1 4 8} \mathbf{~ c c}$ & 2.15 & 6.30 & 6.90 & $\mathbf{7 . 4 9 5}$ \\
Yaglık & $\mathbf{7 5}$ & 4.37 & 4.97 & 5.56 & $\mathbf{4 . 9 6 7} \mathbf{b}$ & 1.69 & 2.29 & 2.88 & $\mathbf{2 . 2 8 8}$ aa & 2.29 & 6.66 & 7.25 & $\mathbf{7 . 8 5 0}$ \\
& $\mathbf{1 5 0}$ & 4.24 & 4.84 & 5.43 & $\mathbf{4 . 8 3 7} \mathbf{c}$ & 1.57 & 2.16 & 2.76 & $\mathbf{2 . 1 6 1} \mathbf{b c}$ & 2.16 & 6.40 & 7.00 & $\mathbf{7 . 5 9 2}$ \\
\hline \multirow{2}{*}{ Nizip } & $\mathbf{0}$ & 3.53 & 4.10 & 4.68 & $\mathbf{4 . 1 0 2} \mathbf{e}$ & 1.22 & 1.80 & 2.37 & $\mathbf{1 . 7 9 6} \mathbf{d d}$ & 1.80 & 4.32 & 4.90 & $\mathbf{5 . 4 7 0}$ \\
Yaglık & $\mathbf{7 5}$ & 4.56 & 5.13 & 5.71 & $\mathbf{5 . 1 3 3} \mathbf{a}$ & 1.65 & 2.23 & 2.80 & $\mathbf{2 . 2 2 7} \mathbf{~ a b}$ & 2.23 & 6.79 & 7.36 & $\mathbf{7 . 9 3 1}$ \\
& $\mathbf{1 5 0}$ & 2.68 & 3.25 & 3.83 & $\mathbf{3 . 2 5 3} \mathbf{g}$ & 0.90 & 1.47 & 2.05 & $\mathbf{1 . 4 7 4} \mathbf{~ f c}$ & 1.47 & 4.15 & 4.73 & $\mathbf{5 . 2 9 9}$ \\
\hline
\end{tabular}

Means in the same column by the same letter are not significantly different to the test of Duncan $(\alpha=0.01)$

Table 2. Relationship between salinity and chlorophyll content in olive cultivar leaves

\begin{tabular}{c|c|c|c|c|c}
\hline CV & IV & DV & RE & DC $\left(\boldsymbol{R}^{2}\right)$ & CC $(\boldsymbol{r})$ \\
\hline \multirow{3}{*}{ Gemlik } & \multirow{3}{*}{ Salinity } & Chlorophyll a & $\mathrm{y}=-0.0023 \mathrm{x}+3.272$ & 0.187 & -0.432 \\
& & Chlorophyll b & $\mathrm{y}=-0.0006 \mathrm{x}+1.6073$ & 0.162 & -0.403 \\
& & Chlorophyll $(\mathrm{a}+\mathrm{b})$ & $\mathrm{y}=-0.0031 \mathrm{x}+4.8948$ & 0.198 & -0.445 \\
\hline \multirow{3}{*}{ Kilis Yaglık } & \multirow{3}{*}{ Salinity } & Chlorophyll a & $\mathrm{y}=0.0006 \mathrm{x}+4.8103$ & 0.152 & 0.389 \\
& & Chlorophyll b & $\mathrm{y}=9 \mathrm{E}-05 \mathrm{x}+2.1925$ & 0.007 & 0.084 \\
& & Chlorophyll $(\mathrm{a}+\mathrm{b})$ & $\mathrm{y}=-0.0038 \mathrm{x}+7.1123$ & 0.373 & -0.611 \\
\hline \multirow{3}{*}{ Nizip Yaglık } & \multirow{3}{*}{ Salinity } & Chlorophyll a & $\mathrm{y}=-0.0057 \mathrm{x}+4.5872$ & 0.203 & -0.451 \\
& & Chlorophyll b & $\mathrm{y}=-0.0021 \mathrm{x}+1.9933$ & 0.182 & -0.426 \\
& & Chlorophyll $(\mathrm{a}+\mathrm{b})$ & $\mathrm{y}=-0.0011 \mathrm{x}+5.7458$ & 0.003 & -0.058 \\
\hline
\end{tabular}

CV: Cultivars; IV: Independent variable; DV: Dependent variable; RE: Regression equation; DC:

Determination coefficient; CC: Correlation coefficient

\section{Polyphenol and protein content}

In the current study, the effects of different $\mathrm{NaCl}$ concentration did not elicit any statistical significant changes in relation to the cv. Gemlik, Nizip Yaglık and Kilis Yaglik but total flavonoids were differently influenced with salt application (Table 3 and Table 4). Even different salt concentration did not induce any statistically significant differences associated with total phenolic content; the highest total phenolic content was ascertained in $150 \mathrm{mM}$ for both cv. Nizip Yaglik. Total flavonoid content decreased with increasing salt concentration in cv. Gemlik. The effects of salt concentration and cultivars were statistically significant in terms of flavonoid content. 
Flavonoid content increased an all cultivars with salt stress. The difference concerned with respect to the concentration was statistically significant at $\mathrm{p}<0.01$. The highest content was determined at $150 \mathrm{mM}$ concentration.

Table 3. Polyphenol and protein content of olive cultivars leaves at different $\mathrm{NaCl}$ concentration

\begin{tabular}{|c|c|c|c|c|c|c|c|c|c|c|c|c|c|}
\hline \multirow{2}{*}{$\begin{array}{c}\text { Olive } \\
\text { cultivars }\end{array}$} & \multirow{2}{*}{$\begin{array}{l}\mathrm{NaCl} \\
(\mathrm{mM})\end{array}$} & \multicolumn{4}{|c|}{ Total phenolics (mg/g GAE) } & \multicolumn{4}{|c|}{ Total flavonoid (mg/g QE) } & \multicolumn{4}{|c|}{ Protein content (\%) } \\
\hline & & I & II & III & Ave. & I & II & III & Ave. & I & II & III & Ave. \\
\hline \multirow{3}{*}{ Gemlik } & $\mathbf{0}$ & 217.8 & 206.7 & 233.8 & 219.4 & 53.47 & 53.39 & 53.16 & $53.30 \mathbf{b b}$ & 0.031 & 0.032 & 0.031 & 0.031 \\
\hline & 75 & 219.6 & 218.7 & 222.9 & 220.4 & 53 & 43 & 51.14 & 51.48 bc & 0.059 & 0.059 & 0.059 & 0.059 \\
\hline & 150 & 216.3 & 229.5 & 23 & .4 & 50 & 6 & 50.21 & 50.42 cc & 0.038 & 0.024 & 31 & .031 \\
\hline \multirow{3}{*}{$\begin{array}{c}\text { Kilis } \\
\text { Yaglık }\end{array}$} & $\mathbf{0}$ & 224.6 & 231.1 & 218.8 & 224.6 & 35.77 & 36.16 & 35.46 & $35.80 \mathrm{gg}$ & 0.019 & 0.029 & 0.023 & 0.024 \\
\hline & 75 & 224.4 & 213.1 & 211.9 & 216.5 & 37.25 & 37.25 & 37.40 & $37.30 \mathrm{fg}$ & 0.057 & 0.067 & 0.062 & 0.062 \\
\hline & 150 & 232.0 & 229.8 & 230.2 & 230.6 & 43.30 & 42.21 & 42.80 & 42.77 ee & 0.025 & 0.024 & 0.024 & 0.024 \\
\hline \multirow{3}{*}{$\begin{array}{l}\text { Nizip } \\
\text { Yaglık }\end{array}$} & $\mathbf{0}$ & 229.2 & 221.4 & 229.6 & 226.7 & 46.64 & 46.72 & 46.17 & $46.51 \mathrm{dd}$ & 0.017 & 0.015 & 0.016 & 0.016 \\
\hline & 75 & 221.3 & 222.0 & 223.4 & 222.2 & 39.34 & 39.34 & 39.50 & 39.39 ff & 0.006 & 0.008 & 0.007 & 0.027 \\
\hline & 150 & 221.3 & 228.4 & 219.6 & 223.1 & 57.63 & 58.49 & 55.47 & 57.18 aa & 0.005 & 0.003 & 0.004 & 0.024 \\
\hline
\end{tabular}

Means in the same column by the same letter are not significantly different to the test of Duncan $(\alpha=0.01)$

Table 4. Relationship between salinity and protein, total phenolic and flavonoid content in olive cultivar leaves

\begin{tabular}{c|c|c|c|c|c}
\hline CV & IV & DV & RE & DC $\left(\boldsymbol{R}^{2}\right)$ & CC $(\boldsymbol{r})$ \\
\hline \multirow{3}{*}{ Gemlik } & \multirow{3}{*}{ Salinity } & Total phenolic & $\mathrm{y}=0.0465 \mathrm{x}+218.57$ & 0.85 & 0.924 \\
& & Total flavonoid & $\mathrm{y}=-0.0192 \mathrm{x}+53.173$ & 0.98 & -0.989 \\
& & Protein content & $\mathrm{y}=-4 \mathrm{E}-20 \mathrm{x}+0.0403$ & $3 \mathrm{E}-32$ & 0.000 \\
\hline \multirow{3}{*}{ Kilis Yaglık } & \multirow{3}{*}{ Salinity } & Total phenolic & $\mathrm{y}=0.04012 \mathrm{x}+220.91$ & 0.178 & 0.422 \\
& & Total flavonoid & $\mathrm{y}=0.0465 \mathrm{x}+35.138$ & 0.902 & 0.950 \\
& & Protein content & $\mathrm{y}=-1 \mathrm{E}-20 \mathrm{x}+0.0267$ & $3 \mathrm{E}-32$ & 0.000 \\
\hline \multirow{3}{*}{ Nizip Yaglık } & \multirow{3}{*}{ Salinity } & Total phenolic & $\mathrm{y}=-0.024 \mathrm{x}+225.81$ & 0.5714 & -0.756 \\
& & Total flavonoid & $\mathrm{y}=0.0711 \mathrm{x}+42.358$ & 0.355 & 0.596 \\
& & Protein content & $\mathrm{y}=5 \mathrm{E}-05 \mathrm{x}+0.0183$ & 0.495 & 0.703 \\
\hline
\end{tabular}

CV: Cultivars; IV: Independent variable; DV: Dependent variable; RE: Regression equation; DC: Determination coefficient; CC: Correlation coefficient

\section{Effects of cultivars and salinity concentration}

The effects of different $\mathrm{NaCl}$ concentration and cultivars on chlorophyll a, chlorophyll b, total chlorophyll, polyphenol and protein content in olive leaves are shown Table 5. Cultivars have given different response to salinity. While there was no statistical difference between the total phenol and protein contents, total chlorophyll, chlorophyll $\mathrm{a}$ and $\mathrm{b}$ content and total flavonoid content were significant. Accordingly, the highest total chlorophyll, chlorophyll a and chlorophyll b content were observed in Kilis Yaglık cultivar and lowest in Gemlik cultivar. In terms of total flavonoid content, Gemlik cultivar was the highest and Kilis Yaglik cultivar was the lowest content. According to the results, while Gemlik was the most and Kilis Yaglik the least affected 
cultivar to salinity. The high flavonoid in the Gemlik cultivaris due to the fact that the cultivar has developed a defense mechanism against salinity.

When the salt concentrations were evaluated, no statistically significant difference was observed between the total phenol and protein contents, but total chlorophyll, chlorophyll a and $\mathrm{b}$ content and total flavonoid content were found to be significant. Accordingly, the highest total chlorophyll, chlorophyll a and chlorophyll b content were observed at $75 \mathrm{mM}$ and the lowest $150 \mathrm{mM}$ concentrations. In terms of total flavonoid content, the highest content was determined at $150 \mathrm{mM}$ and the lowest $75 \mathrm{mM}$ concentrations. Consequently, the effect of salt stress was most at $150 \mathrm{mM}$ concentration. As in cultivars, the high content of total flavonoid at $150 \mathrm{mM}$ shows the effect of the dose level.

Table 5. The effects of different $\mathrm{NaCl}$ concentration and cultivars on Chl a, Chl b, total Chl, polyphenol and protein content in olive leaves

\begin{tabular}{|c|c|c|c|c|c|c|c|}
\hline & & Chl a & Chl b & Total Chl & $\begin{array}{c}\text { Total Phenolic } \\
\text { (mg/g GAE) }\end{array}$ & $\begin{array}{c}\text { Total Flavanoid } \\
(\mathrm{mg} / \mathrm{g} \text { QE) }\end{array}$ & \begin{tabular}{|c|} 
Protein \\
Content $(\%)$
\end{tabular} \\
\hline \multirow{3}{*}{ CULTIVARS } & Gemlik & $3.096 \mathrm{c}$ & $1.561 \mathrm{c}$ & $4.663 \mathrm{c}$ & 222.06 & $51.74 \mathbf{a}$ & 0.040 \\
\hline & Kilis Yaglık & $4.852 \mathbf{a}$ & $2.199 \mathbf{a}$ & $6.827 \mathbf{a}$ & 223.98 & $38.62 \mathrm{c}$ & 0.037 \\
\hline & Nizip Yaglık & $4.163 \mathbf{b}$ & $1.832 \mathbf{b}$ & $5.660 \mathrm{~b}$ & 224.01 & $47.70 \mathbf{b}$ & 0.023 \\
\hline \multirow{3}{*}{$\mathrm{NaCl}(\mathrm{mM})$} & $\mathbf{0}$ & $3.972 \mathbf{b}$ & $1.830 \mathrm{~b}$ & $5.474 \mathbf{b}$ & 223.65 & $45.22 \mathrm{~b}$ & 0.024 \\
\hline & 75 & $4.540 \mathbf{a}$ & $2.066 \mathbf{a}$ & $6.604 \mathbf{a}$ & 219.69 & $42.72 \mathbf{c}$ & 0.049 \\
\hline & 150 & $3.599 \mathrm{c}$ & $1.697 \mathrm{c}$ & $5.073 \mathrm{~b}$ & 226.71 & $50.13 \mathbf{a}$ & 0.026 \\
\hline
\end{tabular}

\section{Discussion}

Cultivars have given different response to salinity in the study. The highest total chlorophyll, chlorophyll a and chlorophyll b content were observed in Kilis Yaglik cultivar and lowest in Gemlik cultivar. It is concluded that Kilis Yaglik variety is more resistant to salt than others. Olives give some physiological and biochemical responces to salinity such as decreasing photosynthesis, stomatal and mesophyll conductance, leaf starch, Rubisco carboxylation rate, actual PSII efficiency etc. (Munns, 1993; Ben Ahmed et al., 2008; Mousavi et al., 2008; Tattini and Traversi, 2009; Remorini et al., 2009). Growth inhibition is a common effect of salinity but in olive tree mechanism of salt effects are prevention of salt translocation, decreasing its transport (Tattini, 1994; Tabatabaei, 2006; Cimato et al., 2010). In the recent studies, physiological, epigenetic, genetic regulation, water status, biochemical and molecular mechanism in olive cultivars under salt stress have been examined and revealed (Abdallah et al., 2018; Trabelsi et al., 2019; Mousavi et al., 2019).

Physiological parameters like $\mathrm{Na}$ accumulation in shoots, decrease in shoot elongation, reduction of maximum photosynthetic efficiency to $\mathrm{NaCl}$ treated plants demonstrate that treated plants perceive the stress (Loreto et al., 2003; Kchaou et al., 2013; Koubouris et al., 2015).

Leaf chlorophyll $(\mathrm{a}, \mathrm{b})$ and total chlorophyll content in various olive cultivars were reported to decline when exposed to the saline conditions (Atia, 2002; Melgar et al., 2008; Shaheen et al., 2011). Halophyte plants demonstrate more protective mechanisms against salt stress concerned with chlorophyll content. Salt at higher concentration in apoplast of cells leads to the ionic toxicity, cellular disequilibrium and hyper osmolality 
and as a result, induction of oxidative stress by increasing formation of reactive oxygen species which causes chlorophyll degradation (Sevengor et al., 2011).

High salt concentrations bring about many problems in the plant cell. These stages are water stress, damages caused by ion toxicity due to high concentration of $\mathrm{Na}$ and $\mathrm{Cl}$ ions in the cell and degradation of $\mathrm{Ca}$ and $\mathrm{K}$ ions in the cell as a result of $\mathrm{Na}$ and $\mathrm{Cl}$ accumulation (Marschner, 1995; Borsani et al., 2003; Xue and Liu, 2008). High salt concentrations negatively affect parameters such as green parts, root development, water use efficiency and root/stem ratio and $\mathrm{K} / \mathrm{Na}$ and $\mathrm{Ca} / \mathrm{Na}$ ratios were found higher in salt resistant plant species (Grewal, 2010).

Differences in salt tolerance are reported among olive tree cultivars. Salinity reduces photosynthesis and stomatal conductance more in salt tolerant than in salt sensitive cultivars according to gas exchange measurement (Tattini et al., 1997). Most of these cultivars such as Manzanillo, Chemlali, Arbequina, Mission, Leccino, Koroneiki, Mastoidis, Frantoio, Cipressino, Allora and Zard response to salinity by decreasing stomatal conductance and photosynthesis (Chartzoulakis et al., 2006; Tabatabaei, 2006; Ben Ahmed et al., 2008; Mousavi et al., 2008; Melgar et al., 2008, 2009; Remorini et al., 2009; Tattini and Traversi, 2009; Tattini et al., 2009; Kchaou et al., 2010). Chétoui variety is moderately sensitive to both drought and salt stress, although it has greater ability to tolerate water depletion. The most significant changes were observed under the salinity stress condition. Under both stress conditions, a greater growth reduction observed due to reduction of all photosynthetic parameters like the integrity of photosystem II and leaf nitrogen content (Abdallah et al., 2018).

Phenolic compound are essential indicators in determination of olive quality. Olive leaves phenolic compounds are significantly influenced by many factors such as genetic factor, harvest time, color, and age (Ranalli et al., 2006). Phenolic components are significant elements in struggle against abiotic and biotic stress factors (Ruiz and Romero, 2001). Phenolic compound biosynthesis and accumulation was stimulated in response to the abiotic and biotic stress factors (Naczk and Shahidi, 2004). However, studies on different species and genotypes have also shown that there may be decreases in total phenolic content with increasing stress factors. Flavonoid content increased and then lipid peroxidation decreased and a negative correlation was reported between lipid peroxidation and flavonoid content under saline conditions (Chutipaijit et al., 2009). Flavonoids have been reported to increase the plant's ability to tolerate stress through affecting physiological performance (Chutipaijit et al., 2009).

It has been reported that the increase in salt doses may affect the amount of free amino acids, although it may lead to reductions in total protein content. Increased acidic and alkaline protease activity increases the amount of free amino acids and provides resistance to stress conditions (Parida et al., 2004).

\section{Conclusion}

As a result, the amount of chlorophyll in the leaves of the olive cultivars decreased with salt stress. Cultivars demonstrated different responses in relation to the salt stress and chlorophyll content. Moreover, while the salt application did not elicit any significant change in terms of total phenolic content, total flavonoid content increased with increasing salt stress. With respect to growth parameters the highest total chlorophyll, chlorophyll a and chlorophyll b content were observed in Kilis Yaglik cultivar and lowest in Gemlik cultivar. It is concluded that Kilis Yaglik variety is more 
resistant to salt than others and Gemlik was the most and Kilis Yaglik the least affected cultivar to salinity. The high flavonoid in the Gemlik is due to the fact that the cultivar has developed a defense mechanism against salinity.

According to the findings of the study, the salt conditions affected the crops at different doses. In addition, the responses of cultivars have been different against salt concentration. Cultivars may develop a defense mechanism against saline conditions through biosynthesizing polyphenols in different amounts. However, chlorophyll content was adversely influenced and consequently, photosynthesis yield is expected to decline under saline conditions.

For further studies, to discriminate the cultivars for their response, enzymatic antioxidant systems of the plants and responsive responses proteins or genes can be revealed. In addition, the results should be compared with the multi-successive year field studies.

Acknowledgement. The current study was a part of MSc thesis "Defense Strategy of Some Olive Cultivars against Salt Stress" written by Sekvan Demir.

\section{REFERENCES}

[1] Abdallah, M. B., Trupiano, D., Polzella, A., De Zio, E., Sassi, M., Scaloni, A., Scippa, G. S. (2018): Unraveling physiological, biochemical and molecular mechanisms involved in olive (Olea europaea L. cv. Chétoui) tolerance to drought and salt stresses. - Journal of Plant Physiology 220: 83-95.

[2] Ahmad, P., Latef, A. A. A., Hashem, A., Abd-Allah, E. F., Gucel, S., Tran, L-S. P. (2016): Nitric oxide mitigates salt stress by regulating levels of osmolytes and antioxidant enzymes in chickpea. - Front Plant Sci 7: 347.

[3] Akbari, M., Mahna, N., Ramesh, K., Bandehagh, A., Mazzuca, S. (2018): Ion homeostasis, osmoregulation, and physiological changes in the roots and leaves of pistachio rootstocks in response to salinity. - Protoplasma 255(5): 1349-1362.

[4] Arnon, D. I. (1949): Copper enzymes in isolated chloroplasts, polyphenoxidase in Beta vulgaris. - Plant Physiology 24: 1-15.

[5] Artajo, L. S., Romero, M. P., Tovar, M. J., Motilva, M. J. (2006): Effect of irrigation applied to olive trees (Olea europaea L.) on phenolic compound transfer during olive oil extraction. - Eur J Lipid Sci Technol 108: 19-27.

[6] Asraf, M., Foolad, M. R. (2007): Roles of Glycine Betaine and Proline in Improving Plant Abiotic Stress Resistance. - Envionmental and Experimental Botany 59: 206-216.

[7] Atia, S. A. (2002): Study on growth of olive plants under salt stress. - PhD thesis, Cairo University, Egypt: 129.

[8] Ben Ahmed, C., Ben Rouina, B., Boukhris, M. (2008): Changes in water relations, photosynthetic activity and proline accumulation in one-year-old trees (Olea europaea L. cv. Chemlali) in response to NaCl salinity. - Acta Physiologiae Plantarum 30: 553-560.

[9] Ben Ahmed, C., Magdich, S., Ben Rouina, B., Boukhris, M., Ben Abdullah, F. (2012): Saline water irrigation effects on soil salinity distribution and some physiological responses of field grown Chemlali olive. - J. Environmental Management 113: 538-544.

[10] Ben-Gal, A. (2011): Salinity and olive: from physiological responses to orchard management. - Israel Journal of Plant Sciences 59: 15-28.

[11] Borsani, O., Valpuesta, V., Botella, M. A. (2003): Developing Salt Tolerant Plants in A New Century: A Molecular Biology Approach. - Plant Cell, Tissue and Organ Culture 73: 101-115. 
[12] Bradford, M. M. (1976): A rapid and sensitive method for the quantitation of microgram quantities of protein utilizing the principle of protein-dye binding. - Analytical Biochemistry 72: 248-254.

[13] Bray, E., Bailey-Serres, J., Weretilnyk, E. (2000): Responses to Abiotik Stresses. - In: Buchanan, B. B., Gruissem, W., Jones, R. L. (eds.) Biochemistry and Moleculer Biology of Plants. Chapter 22, Amer Soc Plant Physiol., Rockrille MD.

[14] Breton, C. M., Warnock, P., Bernille, A. J. (2012): Origin and history of the olive. - In: Innocento, M. (ed.) Olive germplasm. TECH, Rijeka, Croatia: 3-22.

[15] Chartzoulakis, K., Psarras, G., Vemmos, S., Loupassaki, M., Bertaki, M. (2006): Response of two olive cultivars to salt stress and potassium supplement. - Journal of Plant Nutrition 29: 2063-2078.

[16] Chutipaijit, S., Cha-um, S., Sompornpailin, K. (2009): Differential accumulations of proline and flavonoids in indica rice varieties against salinity. - Pakistan Journal of Botany 41: 2497-2506.

[17] Cimato, A., Castelli, S., Tattini, M., Traversi, M. L. (2010): An ecophysiological analysis of salinity tolerance in olive. - Environmental and Experimental Botany 68: 214-221.

[18] Crozier, A., Jaganath, I. B., Cliford, M. N. (2006): Phenols, polyphenols and tannins: An overview. - In: Crozier, A., Clifford, M. N., Ashihaea, H. (eds.) Plant Secondary Metabolites. Oxford, Blackwell, pp: 1-24.

[19] Debez, A., Hamed, K., Grignon, B., Abdelly, C. (2004): Salinity effects on germination, growth and seed production of the halophyte Cakile maritima. - Plant and Soil 262: 179189.

[20] Demiral, M. A., Aktas Uygun, D., Uygun, M., Kasirga, E., Karagozler, A. A. (2011): Biochemical response of Olea europaea cv. Gemlik to short-term salt stress. - Turkish Journal of Biology 35: 433-442.

[21] Grewal, H. S. (2010): Water uptake, water use efficiency, plant growth and ionic balance of wheat, barley, canola and chickpea plants on a sodic vertosol with variable subsoil $\mathrm{NaCl}$ salinity. - Agricultural Water Management 97(1): 148-156.

[22] Hamouda, I., Badri, M., Mejri, M., Cruz, C., Siddique, K., Hessini, K. (2015): Salt tolerance of Beta macrocarpa is associated with efficient osmotic adjustment and increased apoplastic water content. - Plant Biology 18: 369-375.

[23] Kchaou, H., Larbi, A., Gargouri, K., Chaieb, M., Morales, F., Msallem, M. (2010): Assessment of tolerance to $\mathrm{NaCl}$ salinity of five olive cultivars, based on growth characteristics and $\mathrm{Na}+$ and $\mathrm{Cl}-$ exclusion mechanisms. - Sci. Horticulture 124: 306-315.

[24] Kchaou, H., Larbi, A., Chaieb, M., Sagardoy, R., Msallem, M., Morales, F. (2013): Genotypic differentiation in the stomatal response to salinity and contrasting photosynthetic and photoprotection responses in five olive (Olea europaea L.) cultivars. - Scientia Horticulturae 160: 129-138.

[25] Khalid, A. K., Da Silva, J. A. T. (2010): Yield, essential oil and pigment content of Calendula officinalis L. flower heads cultivated under salt stress conditions. - Scientia Horticulturae 126: 297-305.

[26] Kostelenos, G., Kiritsakis, A. (2017): Olive tree history and evolution. - In: Shahidi, F., Kiritsakis, A. (eds.) Olives and Olive Oil as Functional Foods: Bioactivity, Chemistry and Processing. John Wiley \& Sons, Ltd., pp: 1-12.

[27] Koubouris, G. C., Tzortzakis, N., Kourgialas, N. N., Darioti, M., Metzidakis, I. (2015): Growth, photosynthesis and pollen performance in saline water treated olive plants under high temperature. - International Journal of Plant Biology 6: 28-32

[28] Kumaran, A., Karunakaran, R. J. (2006): Antioxidant and free radical scavenging activity of an aqueous extract of Coleus aromaticus. - Food Chemistry 97: 109-114.

[29] Loreto, F., Centritto, M., Chartzoulakis, K. (2003): Photosynthetic limitations in olive cultivars with different sensitivity to salt stress. - Plant Cell Environment 26: 595-601.

[30] Marschner, H. (1995): Mineral Nutrition of Higher Plants. - Academic Press, pp: 657680 . 
[31] Melgar, J. C., Syvertsen, J. P., García-Sánchez, F. (2008): Can elevated $\mathrm{CO}_{2}$ improve salt tolerance in olive tree? - Journal Plant Physiology 165: 631-640.

[32] Melgar, J. C., Mohamed, Y., Serrano, N., García-Galavís, P. A., Navarro, C., Parra, M. A., Fernández-Escobar, R. (2009): Long term responses of olive trees to salinity. Agricultural Water Management 96(7): 1105-1113.

[33] Moretti, S., Francini, A., Minnocci, A., Sebastiani, L. (2018): Does salinity modify anatomy and biochemistry of Olea europaea L. fruit during ripening? - Scientia Horticulturae 228: 33-40.

[34] Mousavi, A., Lessani, H., Babalar, M., Talaei, A. R., Fallahi, E. (2008): Influence of salinity on chlorophyll, leaf water potential, total soluble sugars, and mineral nutrients in two young olive cultivars. - Journal of Plant Nutrition 31: 1906-1916.

[35] Mousavi, S., Regni, L., Bocchini, M., Mariotti, R., Cultrera, N. G. M., Mancuso, S., Googlani, J., Chakerolhosseini, M. R., Guerrero, C., Albertini, E., Baldoni, L., Proietti, P. (2019): Physiological, epigenetic and genetic regulation in some olive cultivars under salt stress. - Scientific reports 9(1): 1093. doi:10.1038/s41598-018-37496-5.

[36] Munns, R. (1993): Physiological processes limiting plant growth in saline soils: some dogmas and hypotheses. - Plant Cell Environment 16: 15-24.

[37] Naczk, M., Shahidi, F. (2004): Extraction and analysis of phenolic in food. - Journal of Chromatography A 1054: 95-111.

[38] Ozkan, A., Kulak, M. (2013): Effects of water stress on growth, oil yield, fatty acid composition, and mineral content of Sesamum indicum. - The Journal of Animal and Plant Sciences 23: 1686-1690.

[39] Özkaya, M. T., Ergülen, E., Ülger, S., Özilbey, N. (2009): Molecular characterization of some selected wild olive (Olea oleaster L.) ecotypes grown in Turkey. - Journal of Agricultural Sciences 15: 14-19.

[40] Ozturk, A., Unlukara, A., İpek, A., Gurbuz, B. (2004): Effect of salt stress and water deficit on plant growth and essential oil content of lemon balm (Melisa officinalis L.). Pakistan Journal of Botany 36: 787-792.

[41] Parida, A. K., Das, A. B., Mittra, B., Mohanty, P. (2004): Salt-stress induced alterations in protein profile and protease activity in the mangrove Bruguiera parviflora. - Verlag der Zeitschrift für Naturforschung 59c: 408-414.

[42] Petridis, A., Therios, I., Samouris, G., Tananaki, C. (2012): Salinityinduced changes in phenolic compounds in leaves and roots of four olive cultivars (Olea europaea L.) and their relationship to antioxidant activity. - Environ. Exp. Botany 79: 37-43.

[43] Ranalli, A., Contento, S., Lucera, L., Di Febo, M., Marchegiani, D., Di Fonzo, V. (2006): Factors affecting the contents of iridoid oleuropein in olive leaves (Olea europaea L.). Journal of Agricultural and Food Chemistry 54: 434-440.

[44] Remorini, D., Melgar, J. C., Guidi, L., Degl'Innocenti, E., Castelli, S., Traversi, M. L., Massai, R., Tattini, M. (2009): Interaction effects of root-zone salinity and solar irradiance on the physiology and biochemistry of Olea europaea. - Environmental and Experimental Botany 65: 210-219.

[45] Ruiz, J. M., Romero, L. (2001): Bioactivity of the phenolic compounds in higher plants. In: Rahman, A. (ed.) Studies in Natural Products Chemistry 25(F): 651-681.

[46] Sevengor, S., Yasar, F., Kusvuran, S., Ellialtioglu, S. (2011): The effect of salt stress on growth, chlorophyll content, lipid peroxidation and antioxidative enzymes of pumpkin seedling. - African Journal of Agricultural Research 6: 4920-4924.

[47] Shaheen, M. A., Hegazi, A. A., Hmmam, I. S. A. (2011): Effect of salinity treatments on vegetative characteristics and leaves chemical content of transplant of five olive cultivars. - Journal of Horticultural Science and Ornamental Plants 3: 143-151.

[48] Singleton, V. L., Orthofer, R., Lamuela-Raventós, R. M. (1999): Analysis of total phenols and other oxidation substrates and antioxidants by means of Folin-Ciocalteu reagent. Methods in Enzymology 299: 152-178. 
[49] Tabatabaei, S. J. (2006): Effects of salinity and $\mathrm{N}$ on the growth, photosynthesis and $\mathrm{N}$ status of olive (Olea europaea L.) trees. - Scientia. Horticulture 108: 432-438.

[50] Tattini, M. (1994): Ionic relations of aeroponically-grown olive genotypes during salt stress. - Plant Soil 161: 251-256.

[51] Tattini, M., Lombardini, L., Gucci, R. (1997): The effect of $\mathrm{NaCl}$ stress and relief on gas exchange properties of two olive cultivars differing in tolerance to salinity. - Plant and Soil 197(1): 87-93.

[52] Tattini, M., Traversi, M. L. (2009): On the mechanism of salt tolerance in olive (Olea europaea L.) under low-or high-Ca2+ supply.-Environmental and Exp. Botany 65:72-81.

[53] Tattini, M., Traversi, M. L., Castelli, S., Biricolti, S., Guidi, L., Massai, R. (2009): Contrasting response mechanisms to root-zone salinity in three co-occurring Mediterranean woody evergreens: a physiological and biochemical study. - Funct. Plant Biolology 36: 551-563.

[54] Tietel, Z., Dag, A., Yermiyahu, U., Zipori, I., Beiersdorf, I., Krispin, S., Ben-Gal, A. (2019): Irrigation-induced salinity affects olive oil quality and health-promoting properties. - Journal of the Science of Food and Agriculture 99(3): 1180-1189.

[55] Trabelsi, L., Gargouri, K., Hassena, A. B., Mbadra, C., Ghrab, M., Ncube, B., Van Staden, J., Gargouri, R. (2019): Impact of drought and salinity on olive water status and physiological performance in an arid climate. - Agricultural Water Management 213: 749-759.

[56] Waśkiewicz, A., Muzolf-Panek, M., Goliński, P. (2013): Phenolic content changes in plants under salt stress. - In: Ahmad, P., Azooz, M., Prasad, M. (eds.) Ecophysiology and Responses of Plants under Salt Stress. New York, Springer: 283-314.

[57] Xue, Y. F., Liu, Z. H. P. (2008): Antioxidant Enzymes and Physiological Characteristics in Two Jerusalem Artichoke Cultivars under Salt Stress. - Russian Journal of Plant Phy. 55(6): 776-781.

[58] Zehtab-Salmasi, S. (2008): Effect of salinity and temperature on the germination of dill (Anethum graveolens L.). - Plant Science Research 1: 27-29.

[59] Zohary, D., Hopf, M., Weiss, E. (2012): Domestication of plants in the old world. - 4th ed., Oxford University Press, New York. 